Published in:

Journal of Modern Greek Studies 33 (2015) 105-126

(C) 2015 by The Johns Hopkins University Press

[p. 105]

\title{
Who Gets Translated and Why? \\ Anthologies of Twentieth-Century Greek Poetry in Poland
}

Joanna Kruczkowska

\begin{abstract}
The translation of Modern Greek poetry in Poland began on a regular basis at the end of the 1960s and falls into two broad categories: anthologies and the poetry of Cavafy. Cavafy's work in Polish rendition must be seen as a separate domain: as in other countries, he has overshadowed the achievements of other Modern Greek poets. There is, however, a significant body of work by other poets available to the reader of Polish in anthologies compiled by prolific and influential translators, whose different backgrounds and motivations generate the question of who has been translated and why. This article demonstrates that the selection of poems and modes of translation are largely driven by extraliterary factors such as sociopolitical conditions, the readership, the publishing market, etc. The resultant Polish texts therefore provide a characteristic example of "rewriting" as defined by André Lefevere.
\end{abstract}

Asked about Modern Greek poetry, the average Polish reader would probably recall the name of C.

P. Cavafy and his "Waiting for the Barbarians." Some would also associate him with the celebrated Polish poet, Zbigniew Herbert, whose work is akin to Cavafy's, especially in terms of poetics, and with Cavafy's most devoted translator, Zygmunt Kubiak. Those who have read Cavafy would also 
remember the debate that swept through the literary and daily press in the 1990s around these translations, concerning mainly the linguistic register of Kubiak's rendition, as well as the more recent one revolving around new versions by Antoni Libera (Kawafis 2011) and Ireneusz Kania (Kawafis 2013). However, Cavafy is by no means the only Modern Greek poet who has been translated into Polish. Five anthologies, several volumes dedicated to individual poets, and a number of publications of Modern Greek poetry in literary journals ranging over fifty years are a substantial output for a country with scarce contacts with Greece.

[p. 106] The overarching categories that will be adopted in this article to characterize motivations behind the translation of Modern Greek poetry in Poland include three vital factors of an extraliterary nature. All relate to the personal background of the twentieth-century anthologiststheir education, language, friendships, and travels, including life in exile-and may be classified under the terms classical tradition, philhellenism, and Greek diaspora. These impulses intersect with processes occurring in the fertile ground of anthologizing Modern Greek poetry in Poland, where one may detect a series of diverse contexts at work. Possibly the pivotal contextual determinant of anthology editing was politics: on the one hand, the outcome of the Civil War in Greece and the rule of the Colonels; and on the other, Poland under Communism, during the period of political transformation, and as a democratic country. Politics exerted a decisive impact on the arts, in the form of censorship and patronage, and on the economy, by regulating supply and demand under the regulated market of Communism. Language, a second key determinant, may also be contemplated in relation to politics; language factors include the changing status of katharevousa vs. demotic Greek and whether Polish or Greek was the translator's primary language. Further concerns to be taken into account include a set of cultural circumstances ranging from the awarding of the Nobel Prize to two Greek poets, to the role of poetry festivals in Poland, to the role of the anthology as a genre, especially in contributing to canon formation.

One can examine many of these factors in the framework of André Lefevere's theory of 
rewriting; as I will argue, Modern Greek anthologies in Poland demonstrate some of the tendencies in editing, criticism, and translation that he defines as methods of rewriting (1992, 4). In his Translation, Rewriting, and the Manipulation of Literary Fame, Lefevere associates "the process resulting in the acceptance or rejection, canonization or non-canonization of literary works" with "power, ideology, institution, and manipulation" (2). Identifying patronage as yet another form of interaction in that process of acceptance or rejection, he defines it as "the powers (persons, institutions) that can further or hinder the reading, writing and rewriting of literature" (15) and clarifies that patronage encompasses ideology (politics, “form, convention, and belief'), economy, and status (16).

Some of the determinants of power, ideology, institutions, and patronage apply to the Modern Greek anthologies compiled in Poland. Together with the circumstances of classical tradition, philhellenism, and the Greek diaspora mentioned in the previous paragraph, they can be classified as extraliterary. Within the complex and diffuse context in which translations of Greek poetry have come together, a number of factors intertwine or overlap with personal determinants, including the translator's enthusiasm, an impulse that Lefevere seems to neglect as a driving force of translation. This article will discuss several instances in which extraliterary context propels the task of the translator [p. 107] and anthologist and leads to the "manipulation" (in Lefevere's words) of the original material and its position in national (Greek and Polish) canons.

\section{Anthologies: determinants and chronology}

The fact that anthologies lend themselves distinctly to the analysis of "who gets translated and why," namely, to critical reflection on rewriting and canonization, is mostly related to the specifics of the genre, which relies on the selection, juxtaposition, ordering, and classification of materials that can be extremely diverse in terms of style and chronology. The politics of inclusion and 
exclusion; the range of information provided in an introduction; and the steering among multiple poetic trends, schools, political profiles, and biographies are among the fields consigned to the personal decision of the anthologist and often the publisher, and thus are extremely susceptible to the processes of rewriting. Canon formation is obviously one of the objectives and dilemmas of anthologies, especially anthologies of foreign literature translated from minor languages unknown to a wider readership. In the cases considered in this article, the anthologists' personal background, combined with social, political, and cultural factors, seem to constitute the principal determinants of how and why Modern Greek poetry is translated and anthologized in Poland. Each of these determinants - classified here as the classical tradition, philhellenism, and the role of the Greek diaspora - is exemplified by one of the three major Polish anthologists of the twentieth century.

Historically speaking, Poland, as a principally Catholic country with greater historical and cultural proximity to Western Europe than to the eastern Mediterranean, had only sporadic direct exchanges with Greece. ${ }^{1}$ This seems to be one reason why there is barely any tradition of teaching the Modern Greek language, as opposed to the classics, which have been essential in humanist education in Poland, just as they have in Western European countries. ${ }^{2}$ Yet it is precisely this classical education that constitutes the first element responsible for Polish interest in Modern Greece and its poetry. A second incentive behind the translation of Modern Greek poetry is philhellenism, the term I apply here in loose connection with the tradition of philhellenism dating back to romanticism, with its travelers and foreign supporters of the struggle for independence in both countries. ${ }^{3}$ A further impetus came from the first and second generation of members of the Greek diaspora who settled in Poland after the Greek Civil War and who have been contributing in various forms to the enrichment of Polish cultural life. These three largely extraliterary aspects have performed key roles in the translation of Modern Greek literature in Poland.

The beginning of the effort to publish Modern Greek poetry in translation occurs in 1960-1961 with the appearance in Polish literary journals of Janusz Strasburger's, Zygmunt Kubiak's and 
Czesław Miłosz's translations of [p. 108] individual poems by Cavafy. The first edition of Cavafy's Selected Poems by Kubiak appears in 1967. The early 1970s belong to anthologies, and the trend is repeated in the turn from the 1970 s to the 1980 s. During this same period Kubiak publishes three more editions of Cavafy. Another peak in publishing activity comes five years later, again with anthologies, as well as with volumes of poetry by Angelos Sikelianos and Kostis Palamas translated by Strasburger, and with the history of Modern Greek literature by Nikos Chadzinikolau (1985). The closing phase of that era begins around 1995 with the publication of Stownik pisarzy nowogreckich (Dictionary of Modern Greek writers) by Strasburger and the release of what is then perceived as the definitive version of Kubiak's Cavafy, accompanied by a monograph on the poet's work and leading to debate in the press concerning that edition. The end of this four-decade period of intensive translation activity by what may be termed the old school is marked by yet another, seventh, edition of Kubiak's Cavafy (2001) and by Chadzinikolau's 2004 study of Odysseus Elytis, including a small selection of his poetry. In the new vein of the twenty-first century, Pawel Krupka edits an anthology featuring younger translators (2004). In this complex chronological pattern we can detect a further extraliterary aspect influencing translation: the existence of a generation of prolific, gifted translators who dominated the market over the previous political era and continue slightly beyond the turning point of the political transition in Poland.

Modern Greek poetry has been more fortunate than prose, of which several works were translated into Polish not directly but via French, English, German, or Russian. ${ }^{4}$ Yet some poets, too, were translated from intermediary languages. Yannis Ritsos, arguably the most famous of Modern Greek poets in the Communist Bloc in the 1950s and early 1960s, did not escape secondary translation (1957 and 1980, the latter from French and English; see Ares Chadzinikolau [2003, 87]) until Nikos Chadzinikolau published his version of The Moonlight Sonata in 1996. Miłosz also admitted to having translated Cavafy from English, which was his frequent practice with lesser known languages: “The translation of Cavafy's poems was taken up from English, unfortunately. 
Given the linguistic features of this poetry, it may turn out to be less harmful than in the case of poets more immersed in the matter of language" $(1972,41-42)$.

In the early 1970 s, a span of only three years sees the publication of three anthologies, each of which represents one of the three overarching categories mentioned above in connection with the translators' background: Kubiak's Antologia poezji nowogreckiej (Anthology of Modern Greek poetry; 1970) can be classified as representative of the classical tradition, Strasburger's Poeci Nowej Grecji (Poets of Modern Greece; 1987, first published in 1972) of philhellenism, and Chadzinikolau's Nowe przestrzenie Ikara (New realms of Icarus; 1972) of the Greek diaspora. This is quite an impressive condensation of translation and anthologizing activity within such a short period of time.

[p. 109] The reasons for such an intensity of publication effort may lie with another extraliterary factor, namely the international focus on Greece because of the military junta of 19671974.

Other determinants of the Modern Greek anthologies boom in Poland are closely linked to the Polish literary market and the system of patronage in which Lefevere includes publishers (1992, 15). In the 1960s and 1970s, Polish state publishers opened up to niche literatures, the most conspicuous example of which was the so-called Ibero-American fever animated by the activity of Zofia Chądzyńska, a gifted translator of Borges and Cortázar. How niche translation connects to the workings of censorship, another form of patronage indicated by Lefevere, is a matter for further inquiry. Certainly, the Communist regime in Poland from time to time published supposedly uncompromising writers - namely those who did not align comfortably with the official party line — to appease public opinion and show a human face abroad. Among Modern Greek anthologists, Chadzinikolau and Strasburger are more or less motivated by the alignment of their political convictions with the demands of Polish censorship, whose tools of rewriting included criticism and editing. To a certain extent, both anthologists can be seen as members of the group described by 
Lefevere as professionals representing "the 'reigning orthodoxy," who are "close to the ideology of patrons dominating that phase in the history of the social system in which the literary system is embedded" (1992, 15). Yet another determinant of anthologizing and a form of patronage, the Nobel Prize, is referred to by Chadzinikolau in his introduction (1972, 13), and by Strasburger in a negative light in many texts. Most probably, it is also operational in the proportions of Kubiak's anthology, almost half of which is devoted to translations of George Seferis's poetry. Other aspects of the publishing market involving economy and patronage - the revival of Greek poetry and the anthology boom on both sides of the Iron Curtain — are also listed in Chadzinikolau's introduction (13).

Classical tradition: Zygmunt Kubiak

The classical background of Zygmunt Kubiak, a specialist in antiquity and translator of ancient Greek and Latin literature, as well as of the English romantics, manifests itself in the introduction to his anthology of 1970. It opens neither with a preface nor with a Greek poem or epigraph, but instead with a translation of a classic English poem on Greek antiquity: John Keats's “Ode on a Grecian Urn." The introduction proper spans the period from Minoan Crete to Mythistorema and Thrush, two "climaxes," as Kubiak calls them, of Seferis's poetry (the rest of which he deems an exercise in style). Twentieth-century Greek history is not mentioned, and the modernist and surrealist traditions are largely overlooked. These facts are inextricably linked to the contents of the anthology.

[p. 110] Who is represented and in what scope? As if out of a sense of duty, Kubiak includes "Ode to Greece (II)" by Andreas Myiaris, ${ }^{5}$ one poem each by Dionysios Solomos, Sikelianos, and Elytis, three by Palamas, a fragment of Digenis Akritas, and a handful of folk songs. The rest of the anthology is taken up by Cavafy (34 poems) and Seferis (also 34 poems). No female poet is 
included. The biographical note on Elytis provides the reader with scant information, suggesting that Kubiak could not estimate the value of Elytis's work ten years before his Nobel Prize, or that he found his poems untranslatable, or that he simply took no interest in his work. What the reader can deduce from Kubiak's anthology is that Modern Greece has basically two primary poets who are equally important (judging from the magical number of 34 poems allocated to Cavafy and Seferis). One wonders what would have happened had it not been for Seferis's Nobel Prize: Kubiak might have allocated to him far less space in his anthology. In other words, the Nobel Prize functioned as a form of patronage promoting the translation of Seferis's work. Although Kubiak did not publish a separate Seferis volume, he did incorporate him in his monograph on Cavafy; in fact, Seferis, translations of his poems, and the process of his liberation from Cavafy's influence occupy a sizeable part of Kubiak's monograph on Cavafy's work Kawafis Aleksandryjczyk (Cavafy the Alexandrian; 1995).

Kubiak's translations of Cavafy and Seferis read well in Polish, which, according to poets and translators such as Miłosz (1994) and Piotr Sommer (2002), is the measure of good translation reaching beyond the principle of accuracy. "As a translator into Polish," Miłosz writes, "I do not really have scruples. A translation should read well, and accuracy is not necessary, it can only be desired" (Miłosz 1994, 14). It is not my aim here to analyze, compare, or evaluate the conformity of the translation to the original regarding the choice of vocabulary, diction, meter, and so forth, especially since Bassnett and Lefevere's discussion of "the translation turn in cultural studies" (1998, 123) has inhibited such reflections. The authors posit the fallacy of “'accuracy' and 'faithfulness' and 'equivalence"” of translation (124), illustrated by means of the so-called Jerome model, which they describe in its simplified form as "the text [which] just needs to be transposed into another language, as faithfully as possible" with the help of good dictionaries (2). Regarding translation as "the study of cultural interaction" (ix), they announce "the days of the Jerome model" as "now numbered, at least in the West" (2). Hence, I will restrict remarks about accuracy to an 
example of mistranslation relevant to the subject, one that must clearly be attributed to Kubiak's classical background: "łby zwierząt ofiarnych" (heads of sacrificial animals) instead of "ofiary"

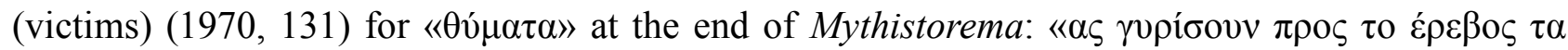

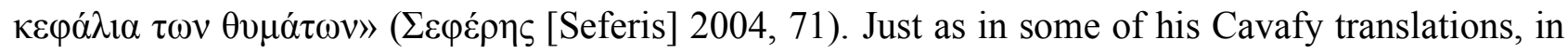
this particular instance Kubiak’s classical expertise (in [p. 111] the case of « $\theta \dot{v} \mu \alpha \tau \alpha »$, his knowledge of the Odyssey) has proven an obstacle rather than an advantage. ${ }^{6}$

The framework of Kubiak's classical education and profession was one of the factors wielding influence on his choices as an editor, translator, and critic: his anthology could serve as a model illustration of Lefevere's concept of editing as rewriting. Kubiak's introduction sets the ancient perspective over the contemporary one in terms of both history as such and literary history. His background as a translator of the English romantics also bears heavily on the introduction, which places Modern Greek poetry in the framework of English poetry on ancient Greece. We could further multiply these layers of rewriting by referring specifically to the English and romantic filters of that antiquity, such as the work of Keats, which seems (at least from his chosen epigraph) to have influenced Kubiak. Yet the most pronounced case of editing as rewriting is revealed by the contents of Kubiak's anthology. The collection establishes an idiosyncratic canon of Modern Greek poetry: idiosyncratic, since hardly any reader would be convinced that any nation's poetry could be virtually reduced to two names. For the sake of comparison, it seems worthwhile at this point to quote Kubiak's opinion on his translations from ancient Greek and Latin, where he openly declares a new, personal canon and invites the reader to follow it $(2002,23-40)$. The difference lies in the relative availability of other versions of the classical canon. At the time of Kubiak's rewriting of antiquity, a plethora of translations from ancient literatures already existed in Poland, and readers might naturally wish to change their perception by reaching for a new one. In the case of Modern Greek poetry, Kubiak's anthology was preceded by a void; his volume thus truly established the canon from scratch. If we consider further a socioliterary factor such as the function of the 
anthology as a genre, which is to include a substantial range of authors representative of the eponymous country, domain, or subject matter and to take into account the readership, which was not familiar with the authors and their background and did not have the opportunity to compare Kubiak's anthology with already existing publications, one comes to the conclusion that Kubiak did not produce an anthology proper. Last but not least, in this case the extraliterary context dominating Polish anthologies overlaps with personal factors determining the domain of Cavafy translation: Kubiak's highly individualized attitude as the editor of the anthology reflects his 35-year preoccupation with Cavafy's work and biography.

\section{Greek diaspora: Nikos Chadzinikolau}

It was a Greek refugee, Nikos Chadzinikolau, who undertook the greatest effort to popularize Modern Greek literature in Poland. The recent history of the Greek diaspora ${ }^{7}$ dates back to the turn of the 1940s and 1950s when Poland [p. 112] admitted over 13,000 Greek refugees from the Civil War, mainly supporters of the Democratic Army of Greece, including over 3,000 real or so-called orphans (Wojecki 1989, 21). Cordially welcomed by Poles heavily tried during the Second World War, the refugees were provided with medical care and housing. Many of the first generation of Greeks in Poland never learned any Polish, as they always expected to return (and indeed some of them did). It was mainly the second generation who assimilated themselves, attending Polish schools and universities. Quite a number of the first generation refused to change their political views and grew disappointed with the system they found in Poland, which did not quite resemble their ideal, just as, years later, many Greek citizens and inhabitants of Greece were astonished that Poles embarked on a path to abolish Communism. History has befallen the two countries in exactly the opposite way: Poland found itself in the range of the Russian/Soviet empire, developing under the latter the tradition of anti-Communist opposition, while Greece in the sphere of competing 
influence created a largely left-wing opposition supported by its special relationship with Russia as the Big Sister in religion, business, and politics. One can imagine how that cocktail confused the minds of the Greek diaspora in Poland, especially since Russia controlled the country tied to it with bonds of compulsory friendship. Some of the first generation of Greek refugees wholeheartedly embraced the Soviet protection, while many of the second generation of Greeks in Poland refuted it just as wholeheartedly. During the student strikes of the 1980s, a number of young Polish Greeks supporting the opposition were sent to Greece with one-way tickets, ${ }^{8}$ which neatly converged with Andreas Papandreou's opening of Greece's borders to Greeks of the Eastern Bloc. On the other hand, in Greece the mythical leftist alliance lived on, dispatching Greek youth to study in Poland in the 1980s despite the dire economic and political crisis in which the country was immersed during that decade.

Nikos Chadzinikolau arrived in Poland at the age of fifteen in 1950, at the climax of Stalinist rule. In that period, a series of "engaged" works of literature (e.g., Flukowski 1951) and novels of little artistic value, translated from Greek via Russian or French, circulated in Poland for propaganda purposes (Ares Chadzinikolau 2003, 66). During his private odyssey, Chadzinikolau was encouraged to settle in Poland by Ivo Andrić, who had been a student at the Jagiellonian University in Kraków before the First World War (Chadzinikolau 1984). After graduating from Poznań University, Chadzinikolau became the author of several anthologies, a history of Modern Greek literature, and a study of Elytis. A poet in his own right, he also translated over 500 Greek authors into Polish and 130 Polish authors into Greek, as his biographical note maintains ("Poznań. Zmarł poeta"). His overall contribution to the promotion of Greek literature in Poland cannot be underestimated and has been recognized with numerous awards. Yet despite these achievements, his output has [p. 113] been treated with reserve by some academics for the reasons that I outline in this section.

Chadzinikolau's anthology of Greek poetry, entitled Nowe przestrzenie Ikara (New realms 
of Icarus), is perhaps the most evident case of numerous extraliterary conditions at work. Taking into account its three editions and wide distribution in bookshops and libraries, it was also possibly the most influential instance of a Greek anthology. Nowe przestrzenie Ikara was in some measure driven by political conviction: both the personal beliefs of the Greek refugee and the official line of the host state. It suffices to quote Chadzinikolau's opinion of the work of Sikelianos, who regarded ancient values as "a chance for the rebirth of the culture of progressive Greece which marches fraternally with other countries" $(1972,7)$, and of Karyotakis, who could not "defend himself against the aggressive expansion of Capitalism" $(1972,8)$. In line with Communist propaganda, the anthology associates decadence and Parnassianism with bourgeois decay, while the working class represents energy, vitalism, and utilitarianism. Such an interpretation of Karyotakis was also advanced by Strasburger. Compliant with the reigning orthodoxy and with the patronage representing it (a state publisher), this tendency clearly exemplifies Lefevere's concept of editing and criticism as a form of manipulation: in this case, by means of the exclusion of the poet who represents Parnassian decadence, an aesthetic trend condemned by the official Communist ideology. Chadzinikolau retains these remarks in two subsequent editions spanning 13 years, though in the first edition (1972) they must have sounded propagandistic and already obsolete: 1972 was decades after the imposition of social realism in Poland (1949) as the only acceptable development of the arts excluding other reactionary trends.

It is undoubtedly easy to castigate now-outdated comments 25 years after the political changeover. One has to recognize the fact that Chadzinikolau must have been motivated by a noble belief in restoring the voices of the repressed, including political prisoners, to the public sphere. Yet the combination of this political predilection with an exuberant, overloaded style (in contrast to Strasburger's reserved scholarly introductions, Chadzinikolau's are those of a poet) and the emotional tone of Chadzinikolaou's introduction justify the above-mentioned reserve among academic circles. The reader is apt to pay more attention to stylistic features than to historical 
information interwoven now and then in the text, much of which concerns the participation of writers such as Yannis Ritsos, Nikiforos Vrettakos, Nikos Pappas, Mitsos Ligizos, Kostas Karachalios, and others in the Resistance, further reflected in the selection of material. The anthology itself assigns a lot of space to post-Civil War leftist poetry, both the first wave mentioned above still expressing the rebellious spirit of the Left, and the second "disillusioned" wave called

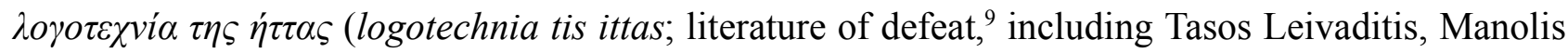
[p. 114] Anagnostakis, Rita Boumi-Papa, Victoria Theodorou, and others). Another criterion for the editor's choice seems to be personal contact with poets, mainly with Boumi-Papa and Nikos Pappas. As a matter of fact, the spectre of the Pappas family haunts not only Chadzinikolau's work but also his son's and Strasburger's-Nikos, Rita, and Lena Pappa are omnipresent references in the anthologists' personal contact lists, critical introductions and biographical notes, and/or are widely represented in the contents of the anthologies.

Regarding Chadzinikolau's choices from the perspective of today's Modern Greek canon (admittedly a shifting list also in Greece itself), some important names are missing (for example, Yiorgos Sarantaris, Nikos Gatsos, Eleni Vakalo, Nikos Kavvadias, Nikos Karouzos, Titos Patrikios, Kiki Dimoula), while some other names have been replaced by different ones in subsequent editions of Chadzinikolau's anthology. The majority of the poets replaced in those later editions are postwar poets; understandably, contemporary literature creates chaos among anthologists, even in the country of origin. One can also comprehend the difficulty of following let alone evaluating current poetic and critical material from abroad, especially by someone from the Soviet Bloc with hardly any access to original Greek sources. Some minor poets may have been chosen because of their participation in poetry festivals in Poland and other countries of the Eastern Bloc, their membership in writers' societies (Ilias Simopoulos, Yannis Goudelis, Yannis Koutsoucheras), their critical output (Andreas Karantonis), and so forth. Still, Chadzinikolau's anthology promotes a more representative canon of Modern Greek poetry than the personal, 
idiosyncratic one proposed by Kubiak, and in this respect comes close to Strasburger's published in the same year, although the criteria used by the two anthologists to a degree create "the canon of the present historical period" (Lefevere 1992, 21) of the target country.

We shall limit the remarks on Chadzinikolau's translation to two aspects related to the extraliterary framework: the combination of his personal contacts and linguistic issues, and his

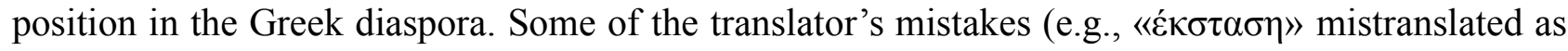

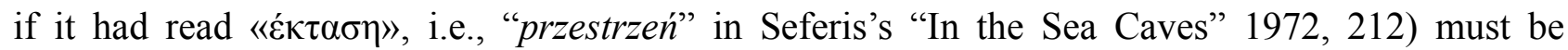
attributed to a lack of meticulousness, as they were not corrected in following editions. Ares Chadzinikolau claims that his father's work was authorized by Greek poets $(2003,145)$. Yet how can a Polish translation be authorized by a foreigner who does not speak Polish? Secondly, Ares Chadzinikolau contrasts these translations with Strasburger's, who, in his opinion, overpoetizes the poems, sacrificing the contents for the sake of the form $(2003,117)$. Strasburger indeed believed in stylistic homogeneity when anthologizing translations $(1971,151)$, an idea that again illustrates Lefevere's concept of rewriting. The correspondence of imagery in Chadzinikolau's translations positively contributes to their accuracy, confirming the benefit of his Greek origin and of his expertise in the [p. 115] source language, especially when contrasted with previous inaccurate translations. Yet Chadzinikolau's slight regard for meter, together with literal choices of vocabulary, at some points fails to create a poetic effect, which Strasburger may-though not necessarilyachieve more easily as a native speaker of the target language.

Chadzinikolau's other anthology, one of maritime poetry (1978), was an original and much needed project, which identified a niche, and thus could become a flagship, as it were, of Greek poetry in Poland and an alternative to the omnipresence of Cavafy. It features Seferis's Mythistorema (though not Thrush, Stratis Thalassinos, or any Cyprus poems), fragments of Nikos Kazantzakis's Odyssey, and a modest choice of Elytis and Ritsos. Vrettakos, primarily a poet of the earth rather than the sea, has also been included, as has Cavafy, the poet of the city, ${ }^{10}$ and a wealth 
of others, including some who had not been included in the previous anthology (Zoi Karelli, Eleni Vakalo, Nikos Karouzos). Yet Nikos Kavvadias, the quintessential Greek poet of the sea, goes missing — because of his specialized marine vocabulary, his exoticism, or for some other reason that remains unaddressed. The introduction provides the reader with detailed information on the meaning of the sea for Greeks, and the volume creates the impression of greater coherence than Nowe przestrzenie Ikara, though a narrower selection immaculately translated would have been a more reasonable option, especially since this anthology was dedicated to perhaps the most characteristic topos in Greek culture.

\section{Philhellenist tradition: Janusz Strasburger}

The most comprehensive of the three anthologies was compiled by Janusz Strasburger, a specialist in the literature of Romance languages, the author of the Dictionary of Modern Greek Writers, and a translator of Greek poetry and prose. Philhellenism is employed here as a category classifying the anthologist's background in a more philological, literal sense, rather than in the historical meaning of the term, and denotes a personal, passionate pursuit of Greek language and culture. It is also applied for the purpose of differentiating Strasburger's linguistic and personal experience from that of the two other anthologists. As a zealous learner of the Modern Greek language, which he believed to be an antidote to the dark years of the Second World War, and eventually as a self-taught Modern Greek speaker whose travels and friendships with writers turned out to be critical in compiling his anthology_Strasburger's background differs from Chadzinikolau's first-hand linguistic and cultural experience and from Kubiak's Classical education as the point of departure. ${ }^{11}$

In its style of presentation and analysis, Strasburger's anthology seems more professional than Chadzinikolau's, offering philological remarks, points [116] on translation, as well as a broad historical and literary background. Both editing and translation have been executed with linguistic 
dexterity, including a variety of lexical and rhythmical patterns. The editor/translator also displays a humbler attitude to the subject: he admits leaving out some famous poems which he was not able to translate without losing the meter. While this obedience to form may suggest that he has fallen prey to the fallacy of accuracy (Bassnett and Lefevere 1998, 124), Strasburger adamantly searches for formal equivalents, which he considers to be equally important to semantic equivalence. In this pursuit, according to the classification by James Holmes, he employs two strategies: the seeking of mimetic form ("illusion of formal sameness," qtd. by Bassnett and Lefevere 1998, 62) and analogical form (an equivalent function of form, e.g., a genre suitable for celebration, mourning, etc.).

Published in two editions, Poets of Modern Greece offers a variety of 80 (1972) and 121 (1987) voices of Modern Greek poetry and is divided into schools and periods. In terms of motivation, Strasburger lists personal reasons, such as his liking for a poem, and literary ones, such as the poem's potential to communicate ideas and lend itself to the purpose of translation. Other extraliterary criteria include a politically incorrect measure applied to the poetry of young women: "Out of young women poets I have chosen the three most beautiful ones: a person dealing with poetry should demonstrate sensitivity to all kinds of beauty" $(1987,34)$. Generally, in Strasburger's and Chadzinikolau's anthologies female poets are underrepresented, occupying about $15 \%$ of the space. ${ }^{12}$ Another apparently linguistic criterion for Strasburger's selection verges on politics: he expresses his affection for the demotic Greek language by excluding poetry written in "the consistently dead language" of katharevousa (1987, 34),namely, works by Andreas Kalvos and the First Athenian School. At the moment of publication, this choice sounded political, especially as Strasburger backed opposition to the junta, with which katharevousa had come to be associated. In his otherwise inclusive introduction, the translator condemns Karyotakis altogether, not only because of the poet's allegedly bourgeois, blasé morbidity, but fundamentally because he believes that Karyotakis's poetry offers nothing new $(1987,22)$. However credible this aesthetic explanation 
may seem, the political context again looms large: in line with Communist propaganda and censorship, Strasburger classifies certain tendencies in art, including Parnassianism, as reactionary. Moreover, the translator disparages $\kappa \alpha \rho v \omega \tau \alpha \kappa \imath \sigma \mu o ́ \varsigma$ (karyotakismos, the imitation of Karyotakis) as an ephemeral craze. Time proved him wrong, as now the qualities of Karyotakis's work are being reassessed in Greece without the earlier personal or aesthetic fanaticism of his followers or detractors.

In the second edition, Strasburger apparently demystifies the canon-forming power of Nikos Pappas, claiming that his Real History of Modern Greek Literature (1973) "extols his own and his wife's merits at the cost of their most [p. 117] noteworthy contemporaries: Seferis, Ritsos, Vrettakos, et al.” $(1987,427)$. (In the same edition, however, Lena Pappa is represented by a larger number of poems than Seferis.) At the same time, in every single publication, the author contends that the Nobel Prize should have been awarded to Palamas, Sikelianos, or Ritsos, and not to Seferis or Elytis, both of whom he labels as "elitist Surrealists"; while this term may apply to the early Elytis, placing Seferis in the group of surrealists is in my opinion a sheer misunderstanding. ${ }^{13}$ Strasburger supports his claim by allocating 26 poems to Ritsos and nine to the Nobelist Elytis. Meanwhile, he presents Seferis as "a more hermetic, less concise version of Cavafy" $(1995,16)$ : "because of his hermeticism [Seferis was] a poet of a minority, ${ }^{14}$ dangerously exposed to the trial of time during which his own myths were gradually dissolving in the myths of his times" $(1995,125)$. Among the Nobel-facilitating reasons for their canonization, Strasburger indicates: the "functions [Seferis and Elytis] performed, numerous acquaintances and contacts abroad" (1987, 439), personal contacts with critics (such as Karantonis) at home, even "the merits of their compatriots who had the misfortune to live and write too early" $(1980,151) .{ }^{15}$ Last but not least, Strasburger points to translation as the reason why the Nobel Committee took interest in both poets: their work had already circulated in other languages because of the supposed ease with which it was translated, whereas "it is far more difficult to render all the qualities of poems by Palamas or Sikelianos than 
by Seferis" $(1995,124)$. And yet, Elytis with his labyrinthine poetics seems as difficult to translate, if not more so, than Sikelianos.

Strasburger's attitude is clearly indicative of political, social, and aesthetic preferences, partly explicit and partly covert but recognizably understated and influenced by the Polish political context. Juxtaposed with Ritsos as the poet of the people and of subdued Communism, Seferis and Elytis embodied the rich middle class (bourgeois or rotten reaction, in the Communist newspeak) who, in addition, did not write comprehensible enough verse to be anointed as poets of the people. ${ }^{16}$ While Ritsos was the first major contemporary Greek poet to be published in Poland (1957), Elytis's poems appeared in the Polish press only after his Nobel Prize. Interestingly, it was Strasburger who translated a selection of Elytis's poems at that point (1980) in the same issue in which he criticized surrealism and the Nobel committee. ${ }^{17}$ If we apply Lefevere's notion of patronage to the Nobel Prize, we can observe a strange phenomenon: despite some attempts made by Kubiak, this form of international patronage did not result in the Greek Nobelists' canonization in Poland. Strasburger's derogatory remarks may have played a role in impeding that process, while translators mastering Modern Greek have been so few that Seferis and Elytis still await their individual collections. Simultaneously, contrary to the Nobelists, the Polish career of another Greek bourgeois "poet of a minority"-Cavafy_was soaring.

[p. 118] Considering Strasburger's generous biographical notes on the friends to whom he dedicated his volume (Kostas Stergiopoulos, Pantelis Prevelakis, the omnipresent Ilias Simopoulos) and his preference for his friends' poems (Lena Pappa versus Seferis), one can see that Strasburger consciously constructs a canon of Modern Greek poetry also according to the key of personal friendships. A great deal of space is reserved for unknown poets, while Andreas Embirikos and Nikos Gatsos are excluded again on the grounds of their alleged participation in the infamous surrealist movement: 
Surrealism was the movement which assumed a more orthodox form in the writings of minor poets who nevertheless . . . did not manage to further develop that ultimately sterile creative method—and soon gave up poetic activity altogether. These are authors such as Nikitas Randos, Nikos Gatsos, Andreas Embirikos, Yorgos Sarandaris, Nikos Engonopoulos, D. Antoniou. $(1987,26)$

Four of these "minor poets" had already long been recognized in Greece as major national literary figures. Strasburger either omits them, just as he does Karyotakis, or stigmatizes them, as in case of the Nobelists, who could not be ignored. At this point, again one can quote Lefevere's belief that translation is determined by, "in order of importance, the translator's ideology (whether he/she willingly embraces it, or whether it is imposed on him/her as a constraint by some form of patronage) and the poetics dominant in the receiving literature at the time the translation is made" $(1992,41)$. We should add that in this case, poetics is inseparably linked to ideology, which dictates the choice of authors and works, while "some form of patronage" equals censorship.

Strasburger adds that his choice of poems is also determined by social interaction, namely, the impatient audience's expectation of diversity $(1987,7-8)$, and by literary factors such as the requirements of the genre of the anthology to illustrate a trend with brief suggestive poems (1987, 34) - brief, we should add, because of space constraints (conciseness) and the requirement that the poems should be characteristic of a poetic tendency as well as appealing to readers (suggestiveness). The editor privileges the quality of translation over the desire to provide a representative selection (Strasburger 1971, 151), as we see also from the contents of his volume. Anticipating criticism, Strasburger states that he carefully "erects an original building"-the anthology_ “defined by personal choice of texts and personal style of translation," believing that the translating profession is absolutely creative and should be highly esteemed (1971, 151). Claiming objectivity of choice as utopian, Strasburger aptly sums up the twentieth-century Modern 
Greek anthology enterprise in Poland. ${ }^{18}$

[p. 119]

New market: twenty-first century

A turnaround in the publication and translation market triggered by political transformation in Poland may be illustrated with a new anthology compiled by Paweł Krupka in 2004. The contemporary translation scene in Poland is reluctant to accommodate young unknown names, and the lack of state-funded translation schemes does not help to ameliorate the situation. Released 17 years after the last (Strasburger's) Greek anthology, Z Parnasu i Olimpu (From Parnassus and Olympus) appeared under the aegis of the Polish Olympic Committee to coincide with "the return of the Olympic Games to Greece" (epigraph). The book's Olympic profile has been accentuated by a section of translations addressing the idea of the games. State patronage and the publishing quota of the previous era ${ }^{19}$ having disappeared, the editor had to turn to other institutions for sponsorship, using the temporal occasion (the Olympic Games) and complying with the expectations of the patron (the Olympic section), thus using a marketing tool. This economic term is consciously employed here, since many of the texts anthologized by Krupka are not related to the Olympic idea, and both the title and the contents attempt to bridge the gap between Olympus and Parnassus. It is hard to determine whether the committee's patronage was honorary or financial, since the editor complains:

The greatest impediment to the development of Modern Greek studies in Poland is the lack of [state] patronage for research, translation or publication. . . Neither can one count on private institutions or foundations. The proof of such an impediment is this publication, owing its existence to the social work of its authors and to the private donations of Greek writers. $(2004,20)$ 
As we can see, translators resort to publishing their own translations in a grass roots campaign. ${ }^{20}$ Beyond the obvious fact that the political change forced a change in patronage, we can pose the question whether the free market economy offers fewer or more opportunities to editors and translators. On the one hand, under Communism there was a huge demand for literature in translation among readers who were hungry for foreign literature and unable to travel abroad; after the political changeover and the opening of restrictions against travel, this demand dropped and new financial support or marketing schemes had to be found or undertaken. On the other, the political changeover has guaranteed freedom of speech and choice uninhibited by censorship, although the liberty of choice may produce a larger sense of loss or chaos in the selected material than in the previous era.

Krupka's collection claims to offer "the first comprehensive overview of Modern Greek literature" (blurb), and is arranged by categories ranging from the Roots(folk ballads) through the New Look at the Classics, Nobel Laureates, [p. 120] Contemporary Greece, to Diaspora (Cyprus, Grecia Salentina, Poland). The editor's criteria in the case of contemporary poetry are subjective and practical: since the book follows the "auteur approach," he has "entrusted the selection of the material to the translators ... and used . . manuscripts lying in their drawers" $(2004,21)$. Such an approach may produce the impression of a certain randomness. One of Krupka's ideas is to amend deficiencies of previous publications: restoring Karyotakis to Polish anthologies is an achievement, and praise should be bestowed on both of his translators (Paweł Majewski and Paweł Krupka) for smooth and interesting renditions. The absence of Palamas, Cavafy, and Ritsos can be justified, to an extent, by the fact that individual volumes of their poetry already exist in Polish translation. "Conscious of the deficiencies of this publication," Krupka states that the anthology "does not attempt a complete presentation of contemporary Greek literature" but "a possibly versatile perspective on it" in the hope of "kindling interest in it among Polish readers" $(2004,21)$. 
It is evident that, in different conditions from the ones experienced by the twentiethcentury anthologists, Krupka has not only sought new sources of financing, but also tried to adapt the task of compiling an anthology to the rapid changes in Polish reality that took place over the preceding 15 years. Although turning to the grass roots (i.e., using "manuscripts lying around the drawers") is by no means a new phenomenon in the world of translation, Krupka's campaign to gather together the work of a number of translators (and, probably, to elicit support from numerous sponsors) was in one respect a more difficult undertaking than that of the previous anthologists who published their own work: Krupka endeavored to reconcile a diversity of voices and genres (poetry, prose, drama, and criticism) with varying levels of success. Besides the general change in publishing policy in Poland, the difference between the anthologists lies in the approach to culture in this country. Once state sponsored and ambitious, though much limited by politics, in the free market culture, anthologies have become one of many consumer goods that have to sell. Krupka's anthology indicates the new range of problems addressed by contemporary Polish editors.

To the lay Polish readers of the past, on the constant lookout for the literature of the Western Bloc but often unable to travel abroad to seek it out on their own, the anthologists' choices were in most cases the only choices available. The workings of censorship were common knowledge, and the requirement that anthologists, like writers, should supply ideological statements (both through their selection of the contents and in the notes to their editions) if they were to be published by major state publishers was regarded by some readers as a lesser evil than the absence of anthologies altogether. Both instances of the complicity between author and reader could paradoxically result in the anthology being perceived as a somehow representative selection of literature - the notion that [p. 121] today, from the different perspective of citizens' rights and freedoms, must obviously be rejected.

In this jigsaw of anthologies of Modern Greek poetry in Poland, one can notice a variety of 
motivations and contexts, almost all of which lead to instances of rewriting and canon formation, or create images of foreign poets and their work. Of the extraliterary factors, the evolving political situation of Poland has possibly exerted the most notable impact on this domain. In my opinion, the case of Polish anthologies of Modern Greek poetry proves that the theory of rewriting applied to this specific area holds better in a highly politicized environment, such as — ideally and ironicallytotalitarian regimes. In democratic systems, it remains a useful theoretical framework but displays a more limited range of application, mainly in the domain of the free market, where publications are subject to financial and marketing pressures. In contrast to the previous political and economic system in Poland, the current system grants the anthologist greater freedom of selection, an easier access to the source culture, and possibly a profounder critical awareness. The greater freedom seems to place constraints on the processes of rewriting stimulated by the external circumstances described above-although these facilitating factors also entail the danger of getting lost in the abundance of the material to be selected. The milieux in which anthologizing, with its processes of rewriting, seems to be flourishing at present are mainly electronic media (blogs and other private websites) and social/ethnic/gender groups previously discriminated against and now also gaining a voice in this specific genre.

Within this liberty of choice, the art of anthologizing should take into account a series of questions and criteria, some of them ethical. What is the real purpose of the new anthology? Does a new translation of particular poems that have been anthologized before challenge the quality of previous translations or does the anthology just follow the publisher's material interest without making qualitative interventions? In determining the vital issue of the proportions of the material presented, one concern is the canon: if the anthology is to compensate for the mistakes of the past, the perplexities of falsification and rediscovery of foreign authors and their work in the source and target countries are definitely sensitive subjects to deal with. Furthermore, since any anthology may prove to be the reader's first encounter with the literature of the source culture, the fundamental 
points of professional ethics such as responsibility in representing the material come into play. In our age of globalization, instant travel, and the Internet, the reader's growing access to sources and the awareness this may bring can no longer be ignored as a significant determinant of the anthology market. Yet another question related to canon formation concerns novelty. In Modern Greek poetry translation in Poland, much still remains to be done, while the Greek canon, as many others, is prone to be rewritten according to several factors, including extraliterary ones. Last but not least, the future of the [p. 122] book has been declared precarious, while the likelihood of discovering foreign cultures via languages and literatures considered to be exotic has drastically dwindled; instead of mental travel, most consumers opt for all-inclusive tours. Hence, anthologizing is becoming a more and more challenging enterprise, and the translator consequently faces a new set of miscellaneous complexities of rewriting. 


\section{REFERENCES CITED}

Bassnett, Susan, and André Lefevere. 1998. Constructing Cultures: Essays on Literary Translation. Clevedon: Multilingual Matters.

Bzinkowski, Michał. 2013. "Jorgos Seferis: Mityczna historia” [George Seferis: Mythistorema]. Przegląd Polityczny 120:114-125.

Chadzinikolau, Ares. 2001. Polsko-greckie zwiąki społeczne, kulturalne i literackie w ciagu wieków [Polish-Greek social, cultural, and literary relations through the ages]. Poznań: G\&P.

2003. Literatura nowogrecka w przekładach polskich [Modern Greek literature in Polish translation]. Poznań: Poeticon.

Chadzinikolau, Nikos, ed., trans. 1972. Nowe przestrzenie Ikara. Antologia poezji greckiej XX wieku [New realms of Icarus. Anthology of twentieth-century Greek poetry]. 2nd ed. 1980, 3rd ed. 1985. Poznań: Wydawnictwo Poznańskie.

1978. Latarnie Posejdona. Antologia greckiej poezji morskiej XX wieku [The lighthouses of Poseidon: Anthology of twentieth-century Greek sea poetry]. Gdańsk: Wydawnictwo Morskie.

Chadzinikolau, Nikos. 1984. "Drugi dom Odysa" [Odysseus's second home]. Interview by Zbigniew Chomicz. Radar 13 (29 March). 
1985. Literatura nowogrecka 1453-1983 [Modern Greek literature 1453-1983]. Warsaw, Poznań: PIW.

2004. Odisseas Elitis—poeta światta i morza [Odysseus Elytis: The poet of light and the sea]. Poznań: Wydawnictwo Naukowe UAM.

Flukowski, Stefan., ed., trans. 1951. Krwia serca-zbiór dokumentów, listów i wierszy greckich ofiar monarcho-faszyzmu i anglosaskiego imperializmu [Written in the heart's blood: A collection of documents, letters, and poems by Greek victims of monarcho-fascism and Anglo-Saxon imperialism]. Warsaw: KiW.

Ganaciu, Maria, and Stanisław Srokowski, eds., trans. 1990. Ciało z grzechu. Greckie wiersze miłosne [The body of sin. Greek love poems]. Kraków: Miniatura.

1992. Poetki miłości. Wybór wierszy współczesnych greckich poetek [Poets of love.

Selection of poems by contemporary Greek women poets]. 2nd ed. Wrocław: Ośrodek Kultury i Sztuki. First published 1985.

Greek Press Office in Warsaw. 2009. "Read in Translation: Meeting with Translators in Warsaw." 26 February 2009. Joint project by the European Union National Institutes for Culture cluster in Warsaw, the Greek embassy, and the National Book Market Information Point. Accessed 29 August 2012. http://greeceinfo.wordpress.com/?s=translation. 
Kawafis, Konstandinos (Cavafy, C. P.). 2011. Jeżeli do Itaki wybierasz się w podróż... [As you set out for Ithaca...]. Translated by Antoni Libera. Kraków: Znak.

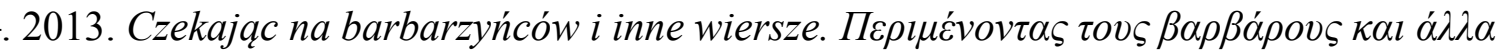
$\pi o \imath \eta ́ \mu \alpha \tau \alpha$. Translated by Ireneusz Kania. Kraków and Budapest: Austeria.

Krupka, Paweł. 2004. Z Parnasu i Olimpu-przegląd greckiej literatury współczesnej [From Parnassus and Olympus: Contemporary Greek literature reader]. Warsaw: Heliodor.

Kubiak, Zygmunt. 1970. Antologia poezji nowogreckiej [Anthology of Modern Greek poetry]. Warsaw: PIW.

1995. Kawafis Aleksandryjczyk [Cavafy the Alexandrian]. Warsaw: Tenten.

2002. Zwierciadło Śródziemnomorza [The mirror of the Mediterranean]. Warsaw:

Bertelsmann and Tygiel Kultury.

Lefevere, André. 1992. Translation, Rewriting, and the Manipulation of Literary Fame. New York: Routledge.

Miłosz, Czesław. 1972. Prywatne obowiązki [Private obligations]. Paryż: Instytut Literacki. 1994. Wypisy z ksiag użytecznych [A book of luminous things]. Kraków: Znak.

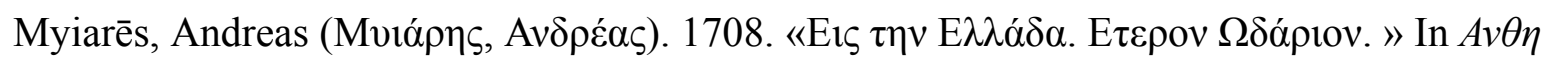

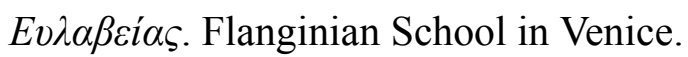


Palamas, Kostis. 1987. Poezje [Poems]. Translated by Janusz Strasburger. Warsaw: PIW.

Pieris, Michael. 1989. “Cavafy and the Sea.” Journal of Modern Greek Studies 7 (2): 273-286.

"Poznań. Zmarł poeta Nikos Chadzinikolau [Nikos Chadzinikolau: Obituary].” Gazeta Wyborcza. 6 November 2009. Accessed 4 Aug 2013. http://wyborcza.pl/nekrologi/1,101499,7229101,Poznan_Zmarl_poeta_Nikos_Chadzinikol au.html.

Ritsos, Yannis. 1957. Sonata księżycowa [The moonlight sonata]. Translated by Jan Zych. Zebra 4 : $8-9$. 1980. Sonata księżycowa. Poematy $i$ wiersze [The moonlight sonata. Long and short poems]. Translated by Michał Sprusiński. Warsaw: Czytelnik. 1996. Sonata księżycowa [The moonlight sonata]. Translated by Nikos Chadzinikolau. In Najstynniejsze poematy XX wieku [The most famous long poems of the twentieth century]. Kraków: Sponsor.

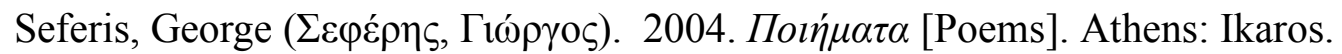

Sikelianos, Angelos. 1985. Poezje [Poems]. Translated by Janusz Strasburger. Warsaw: PIW.

Sommer, Piotr. 2002. "Tkać i pruć" [Weaving and unstitching]." Interview by Barbara N. Łopieńska. Tygodnik Powszechny 16 (21 April). Accessed 12 December 2013. 
http://www.tygodnik.com.pl/numer/275416/sommer.html.

Strasburger, Janusz. 1971. “Z warsztatu thumacza [The translator's workshop].” Literatura na Świecie 1: 149-153.

1980. "Na marginesie ostatniej literackiej nagrody Nobla" [On the last Nobel Prize in Literature]. Literatura na Świecie 2 (106): 147-153.

1987. Poeci Nowej Grecji [Poets of Modern Greece]. 2nd ed. Warsaw: Czytelnik. First published 1972.

1995. Stownik pisarzy nowogreckich [Dictionary of Modern Greek writers]. Warsaw: Wiedza Powszechna.

Wiersze w metrze [Poems on the underground]. Instytut Książki and British Council. 2008, 2009. 29 August 2012. http://wierszewmetrze.eu/2008 [2009].

Wojecki, Mieczysław. 1989. Uchodźcy polityczni z Grecji w Polsce 1948-1975 [Greek political refugees in Poland 1948-1975]. Jelenia Góra: Karkonoskie Towarzystwo Naukowe. 1999. Polacy i Grecy - zwiazki serdeczne [Poles and Greeks: convivial relations]. Wolsztyn: Pryzmat. 
${ }^{1}$ For further information see Wojecki (1999) and Ares Chadzinikolau (2001). Perhaps the most famous Polish family in Greece was the Mineyko family: Zygmunt Mineyko was the key fortification engineer of Epirus and the discoverer of Dodona, while his daughter Zofia was the wife of Georgios Papandreou and the mother of Andreas Papandreou, the first Western visitor to General Wojciech Jaruzelski (First Secretary of the Polish United Workers' Party, responsible for imposing martial law in Poland in 1981-83). .

${ }^{2}$ The beginning of very limited Modern Greek language instruction at Polish universities dates back to 1956 (Ares Chadzinikolau 2003, 62). The first outline of Modern Greek literature was written by Kazimierz Bulas in 1933 (Ares Chadzinikolau 2003, 47). Since I came across Ares Chadzinikolau's study when I had already finished this article, I refer to it mainly in the footnotes. In my references, in order to differentiate Nikos Chadzinikolau from his son, Ares, I always supply Ares's first name.

${ }^{3}$ The most famous Polish traveler to Greece was the great romantic writer Juliusz Słowacki, who devoted some of his best known poems to those travels and made acquaintance with Solomos on one of his sea voyages. As for the Greek war of independence, volunteers from Poland, impeled by the Polish military ethos of supporting the struggle for liberation in other countries as a common cause, took part in the battles of Peta and Mesologgi.

${ }^{4}$ The same fate has befallen Polish poetry in Greece. The only available Anthology of Polish Literature in Greek, edited by Kostas Valetas, was translated from French (Ares Chadzinikolau 2003, 96).

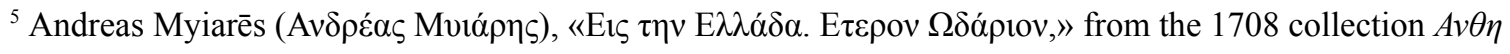
Evi $\alpha \beta \varepsilon i \alpha \varsigma$, published by the Flanginian School in Venice.

${ }^{6}$ It would be interesting to compare Kubiak's translation of Seferis's Mythistorema to Michał Bzinkowski's new version (2013), for instance in terms of punctuation, for which Kubiak keeps to the Polish system while Bzinkowski tries to preserve Seferis's irregularities "when possible," challenging not only the system of Polish grammar but also the polysystem of Polish poetry with its various modes. In this respect, Bzinkowski's model can be classified as "the Horace Model" (Bassnett and Lefevere 1998, 3-7), that is, translation that negotiates between the source and target languages but is "always slanted towards the privileged language" (4), in Bzinkowski's case, Modern Greek.

${ }^{7}$ I use the terms "diaspora" and "refugees" interchangeably here since the Greek diaspora in Poland consists of, with few exceptions, the Greek Civil War refugees and their descendants.

${ }^{8}$ One of them was Odysseas Konstantinopoulos, a Polish-Greek composer now active in Athens, whom I interviewed twice, in 2011 and 2012. The remaining factual information included in this paragraph comes from these interviews, from Nikos Ruskietos, Director of the Greek Music Festival in Zgorzelec (private conversation 2011), and from my conversations with Greeks in Greece; conclusions in the paragraph are mine. The issue of refugees' identity could be the subject of a book. For more on the early history of the Greek diaspora in Poland, see Wojecki (1989). 
${ }^{9}$ The term “literature of defeat" emerged after Khrushchev’s 1956 revelations about Stalinism.

${ }^{10}$ Cf. Pieris's argument for sea motifs in "Cavafy and the Sea” (1989).

${ }^{11}$ Kubiak's experience with ancient Greek corresponds to Strasburger's with Modern Greek: he started to learn it during the war, at the age of 13, in order to "escape into the world of ideas" (Kubiak 2002, 5).

${ }^{12}$ A selection of love poems by women, including Kiki Dimoula, Katerina Anghelaki-Rooke, Pavlina Pampoudi, and Olga Votsis (Ganaciu and Srokowski 1992), slightly compensates for this absence. Another anthology in this category features both women and men (Ganaciu and Srokowski1990).

${ }^{13}$ Chadzinikolau's opinion is apparently contrary to Strasburger's but does not do justice to Elytis's poetry either: "Greek poetry . . . is philosophical but communicative, devoid of vain attempts at experimentation or word play, promoting humanist values, which has been proved by two Nobel Prizes after the war" (1984, emphasis added).

${ }^{14}$ The Polish reads “poeta mniejszości," literally “poet of a minority.” Here Strasburger is referring to Seferis's origins in the Greek community in Asia Minor.

${ }^{15}$ He claimed that awarding the Nobel Prize to Elytis may have been dictated by the celebration of the 70th birthday of . . Ritsos, in order to block the prize for that "progressive" writer supported by "progressive" critics (1980, 151).

${ }^{16}$ This was contradicted by their popularity in Greece when Seferis's and Elytis's poems were set to music.

${ }^{17}$ Incidentally and ironically, during this same year the Nobel Prize was awarded to Strasburger's compatriot, Czesław Miłosz.

${ }^{18}$ I will not discuss Strasburger's volumes of Palamas and Sikelianos except to make two remarks. First, he admires both authors for being prolific and inspired, feeling in his element in the metrical systems of the former. Second, he opens both volumes with in-depth introductions to the respective poet's work, yielding, however, to the conspiracy theory that the Greek government blocked attempts to award the Nobel Prize to Sikelianos or Kazantzakis (Sikelianos 1985, 12). Discussing the difficulties of establishing the Palamas canon, he promotes his own selection: valuing most the selections of George C. Katsimbalis and Theodore Ph. Stephanides, and of Andreas Karandonis in their respective editions, he nonetheless suggests eliminating one-fourth of the contents of those volumes (Palamas 1987, 11).

${ }^{19}$ By "quota" I mean a defined number of translations to be published in a defined period of time. Communist economy worked on the basis of state plans or schemes, established by the Communist party usually for the following five years.

${ }^{20}$ Other instances of such activities are projects that recognize the difficulty in reaching publishers and readers. Read in Translation was a joint initiative of the European Union National Institutes for Culture (EUNIC) cluster in Warsaw, embassies (including the Greek embassy), and the National Book Market Information Point representing the Frankfurt Book Fair in Poland. The aim was to "promote valuable contemporary European literature; open up a debate 
on literary translation and the profession of the translator; and support young gifted translators who so far have not had a chance to emerge in the market" (Greek Press Office in Warsaw). The project, which lasted two years, followed a formula of meetings at which translators read excerpts from their work to be published in a nonmainstream literary magazine and at the professional portal of publishers. Wiersze $w$ metrze (Poems on the underground), the British Council initiative tested in many European capitals, invited Titos Patrikios, Nasos Vayenas, Dinos Siotis, and others to contribute to the project, which included poems on trains and projections onto screens, poetry slams, and a welldesigned website, which unfortunately no longer exists. 